\title{
Human Indifference Towards Suffering of Others Depicted in 'Morning at the Window' by Yeats \&' Musee des Art' by Auden
}

\author{
Mohamed Jabraddar Mahil Abdallah ${ }^{1}$ \\ ${ }^{1}$ Department of Languages and Translation, Faculty of Education and Arts, Northern Border University, Arar, \\ Saudi Arabia \\ Correspondence: Mohamed Jabraddar Mahil Abdallah, Department of Languages and Translation, Faculty of \\ Education and Arts, Northern Border University, Arar, Saudi Arabia.
}

Received: May 4, 2021; Accepted: May 21, 2021; Published: June 1, 2021

\begin{abstract}
The current study has sought to examine human suffering as depicted in 'Morning at the Window', by W.B. Yeats and 'Musee des Beaux Art', by W. H. Auden. It has also attempted to investigate how humans are incurious and unenthusiastic to man's serious problems and disasters. In order to achieve the aims of this study, the two poems under investigation were, quantitatively, analyzed. The expressions, in the two poems, which indicate that human are indifferent and lukewarm to human serious problems and disasters; were focused and investigated. The findings of the study showed that the poems, investigated in this study, shed light on human suffering. They also displayed that humans are incurious and unenthusiastic to man serious problems and disasters. Moreover, they show an insensitive and cruel disregard for others. The study recommends that future researches and studies should be conducted on other forms of literary genres other than poetry. Besides, examining other social issues that of great importance to humanity, for literature is regarded as the mirror which reflects human life in all its aspects.
\end{abstract}

Keywords: social issues in poetry, human suffering in poetry, human indifference in poetry

\section{Introduction}

Poetry plays a vital role in social issues by emphasizing aspects which of great importance to humanity. It has a potential ability to depict man's pleasure and depression, calm and agitation, poverty and opulence, stability and volatility. So, it is thought to be a mirror through which all social issues can be seen. Poetry is also regarded as a venue for understanding human social problems and how well they are able to be solved. Thus, it shapes a fertile field for discussion and analysis that leads to elevated intellectual and creative ideas among various audience which may offer a special and a new way of thinking. Therefore, poetry gains its significance in influencing human life by drawing attention to what takes place in the world around man. In addition, poetry functions as a tool through which human emotions and feelings are expressed. Besides, poetry is a rich field which enables people to be aware of various social issues that surround the world and shape it. Thus, it functions as a critic mechanism of these social issues by shedding light on them and evaluating them, as well. Hence, poetry enables audience to see the world from a new perspective and widens their cultural, social and political knowledge. One of the vital aspects of poetry is that it can offer pleasure and invitation to enjoy all aesthetic of life with its nature. Based on what has already mentioned above, this study attempts to investigate human indifference to the suffering of others depicted in 'Morning at the Window' W. B. Yeats and 'Musee des Beaux Arts' by W.H. Auden.

\section{Statement of the problem}

Among literary genres, poetry is regarded as the most difficult and intricate one; and that can be due to its special language in terms of its diction, interrupted structure, form and literary devices. So, poetry tends to utilize language in a special way and deviate from everyday language. It is noticed that the language of poetry is made different from ordinary language. Besides, its subjectivity of interpretation by different readers in different contexts because it has more meanings and indications to offer. Therefore. poetry is believed to be limitless in its content and form. One can say that it is almost difficult to understand a poem from the first time of reading or listening to it. Wainwright (2018), asserts that comprehending a poem is sometimes difficult, it can require that we recognize and understand the convention within which it is working. Stephen (1984), argues that poetry is often thought of as the most difficult of the three literary modes or genres. He also states that poetry can be obscure and it can be hard to understand it. Matterson and Jones (2000), report that a poetic form is something considered abstruse which makes it difficult to be understood. The hidden meaning of poetry is also another aspect which displays the difficulties 
encounter audience in understanding and interpreting poetry. Zapruder (2017), makes an argument that in schools they were taught that poetry is inherently difficult and that by its very nature it, somehow, makes meaning by hiding meaning.

\subsection{Aims of the Study}

1. The poems under investigation highlight human suffering.

2. The pomes examined draw attention to human indifference towards suffering of others.

\subsection{Significance of the Study}

The current study seeks to contribute to the efforts exerted in facilitating poetry and make it easy to be understood by different audience who are interested in poetry in different contexts. By doing so it tries to explore the hidden meaning behind poems in order to enable audience have a better understanding of these poem. Consequently, they are able to be aware of the possible meanings and themes conveyed by the poets. Moreover, the study may be of magnificent benefits to the students studying poetry, as well as to teachers. Students can comprehend and discover various themes of the poems which they lend themselves to several interpretations. So, their intellectual skills, critical thinking and communicative abilities improve and develop. For teachers, such a study can function as a source which helps them in teaching poetry.

In addition, the study may function as a model that offers great support to the researchers in the field of literature, in general, and the field of poetry in particular. Finally, this study can encourage researchers in order to conduct various studies in poetry because it is noticed that there are few studies carried in this domain compared to other fields of studies.

\subsection{Research Questions}

1. How do the poems shed light on human suffering?

2. What indifference of human towards man suffering expressed by the poems?

\subsection{Research Hypotheses}

1.The poems shed light on human suffering.

2. Human are incurious and unenthusiastic to man serious problems and disasters.

\subsection{Theoretical framework and Literature Review}

Poetry has different benefits and various roles which it can play in human lives and have great influence. In terms of education, poetry enables learners to be aware of literary genres and concepts associated with poetry throughout different stages of history. Besides, the distinctive use of the various elements of poetry such as diction, tone, form, imagery, figure of speech and symbolism. In addition, it develops learners analytical and communicative skills and critical thinking. Simpson (2003), believes that in linguistic terms, the poem exploits the interaction between the written system of language principles of word-formation and psycholinguistic perceptual strategies. Deployed throughout the text are devices which manipulate the visual medium of language, devices which are combination of visual tricks and striking morphological structure can be reviewed as a product of the complex intersection of the graphological and morphological system. Poetry also has its considerable and prominent impact in man political religious and social lives. Watson (1992), argues that all the Romantic poets are compassionate about the poor, and sceptical about the use of political power and religious influence. Poetry communicates feelings, emotions, nostalgia that can have the ability to stir up the world by emphasizing the role of nature in creating an atmosphere of beauty and charm. Abd Allah (2021), conducted a study to examine the value of night in the English poetry of the Romantic period (1757-1822). The study aimed to establish how the writers of the English poetry of the Romantic period highlight the value of night and images of nature involved in creating this value, while also realizing the importance of night in life, according to the poems investigated in the study. Results showed that the romantic poets highlight the value of night as an image of nature. In addition to, the poets believe that night is a sign of beauty and tranquility of human life. Some arguments articulate the critical and communicative skills that can be acquired by studying poetry. Simecek and Rumbold (2016), believe that the experience of poetry can offer crucial 'thinking spaces' in which to reflect on our lives, thereby enhancing understanding of the self through personal engagement with a poem. Poetry, also, according to some claims, can function as has a therapeutic impact on the mind. AShah, Bija (2018), argues that both writing and reading poetry, through their expression of feelings and words have highly therapeutic effect on the mind. Thus, poetry gains the possibility to relieve and remove various hardships, tension and psychological problems. Another vital aspect of poetry which is highlighted in some researches, is that it offers the ability to man so as to see the world and reshape it according to his views and critical thinking. Handley (2021), states that poetry articulates lessons that tell us in order to dwell on the earth we shouldn't 
rely on tradition and habit to teach us how to see the world. As the restored of the creation suggests, seeing it as new, even when it is already old, is the first step in living morally in the natural world.

\section{Method}

\subsection{Data Collection}

\subsubsection{Materials}

The materials assigned for this study are two poems. The first poem investigated is 'Morning at the Window', by Thomas Stearns Eliot (1888-1965). While the second one is 'Musee des Beaux Arts', by Wystan Hugh Auden (1907-1973).

\subsubsection{Procedures}

Seeking to achieve the objectives of the current study, two poems were selected. Both selected poems belong to modernist poetry written, mainly, in Europe and Northern America (1890-1950). The expressions, in the two poems, which indicate that humans are incurious and unenthusiastic to man serious problems and disasters; are focused and investigated.

\subsection{Data Analysis, Discussion and Interpretation}

The following section is assigned in order to discuss human suffering and the indifference towards the suffering of others as introduced by the two poems examined in this study.

\subsection{Data Analysis}

The data of the current study will be shown by tables which will explain the distribution and the frequency of the expressions, words and phrases, that point to the suffering of the poor people as presented in the two poems examined in the current study. The intended analysis will show the great suffering and misery of the poor.

Table 1. Distribution of the Expressions Showing the Suffering of the People and Humans indifference towards them in 'Morning at the Window', by Eliot.

\begin{tabular}{|l|l|}
\hline Expressions Showing Humans Suffering & Humans Indifference towards others \\
\hline Rattling breakfast plates in basement kitchens & No attention towards the misery and sadness of others \\
\hline Damp souls of housemaids & \\
\hline The brown waves of fog toss up to me & \\
\hline Twisted faces & \\
\hline Tear from a passer-by with muddy skirts & \\
\hline An aimless smile that hovers in the air & \\
\hline
\end{tabular}

Table 2. Distribution of the Expressions Showing the Suffering of the People and Humans indifference towards them in 'Musee des Beaux Arts, by Auden

\begin{tabular}{|l|l|}
\hline Expressions Showing Humans Suffering & Human Indifference towards others \\
\hline About suffering they were never wrong & No attention towards the suffering of others \\
\hline The dreadful martyrdom & someone else is eating or \\
\hline The splash, the forsaken cry & opening a window or just \\
\hline The white legs disappearing into the green water & walking dully along \\
\hline A boy falling out of the sky & the dogs go on their doggy life \\
\hline
\end{tabular}

\section{Discussion}

'Morning at the Window' by Thomas Stearns Elliot

They are rattling breakfast plates in basement kitchens,

And along the trampled edges of the street

I am aware of the damp souls of housemaids 
Sprouting despondently at area gates.

The brown waves of fog toss up to me

Twisted faces from the bottom of the street,

And tear from a passer-by with muddy skirts

An aimless smile that hovers in the air

And vanishes along the level of the roofs.

Eliot presents this poem through a lyrical voice depicting what he sees through the window in the morning. He intends to highlight an everyday scene of workers and housemaids displaying their sadness, misery and disappointment.

At the outset of the poem, the poet points to the daily suffering of the poor workers and housemaids. They have, compulsory, to start their daily suffering by getting up early in the morning and prepare their breakfast. The poor people, who seem to live in a slum, rattle their breakfast, then they leave home and go to the city. Their dwelling in basement, shows their poverty, because they are not able to live in better houses. So, this is a prominent sign of those people's misery and hardships. Of course, to live entirely below the ground level may cause various serious diseases. However nobody attempts to offer any sort of help or support. The journey of the poor shifts to another scene; when they go to the city they take trampled streets. Therefore, they are confronted by many difficulties when they go on those roads. Under those circumstances, the poet says that he is aware of the depression and sadness of the housemaids who are sprouting despondently at the areas gates of the city. Thus, they start their daily life in an atmosphere full of disappointment and despair.

The second stanza portrays another aspect of the indigent's suffering by showing that they are forced to leave home; even when the brown waves of fog, due to the polluted air that spread in the air. This indicates that the poor people are forced to leave under any condition, whether it is rainy, windy, hot or foggy. Nobody is going to excuse them or have any sense of pity or sympathy towards. They are, unfortunately, exploited by unkind and heartless humans who lack all senses of humanity. As a result, they come to work with twisted faces which reflect their deep misery and agony. The sadness and disappointment are expressed by the different images that Eliot presents which include the tear of a passer-by with muddy skirts; indicating that they are unable to have good clothes, and the aimless smile which can been seen on their faces. So, those miserable poor people are unable to smile and forget about their suffering and difficulties.

In general, Eliot highlights a gloomy appearance of humans life; displaying their calamity towards the misery and depression of others. It seems that the poets is addressing the society in order to arouse man's conscience and call him to be kind and pitiful to the poor.

\section{"Musee des Beaux Arts', by W.H. Auden}

About suffering they were never wrong,

The old Masters: how well they understood

Its human position: how it takes place

While someone else is eating or opening a window or just walking dully along;

How, when the aged are reverently, passionately waiting

For the miraculous birth, there always must be

Children who did not specially want it to happen, skating

On a pond at the edge of the wood:

They never forgot

That even the dreadful martyrdom must run its course

Anyhow in a corner, some untidy spot

Where the dogs go on with their doggy life and the torturer's horse

Scratches its innocent behind on a tree.

In Breughel's Icarus, for instance: how everything turns away

Quite leisurely from the disaster; the ploughman may

Have heard the splash, the forsaken cry, 
But for him it was not an important failure; the sun shone

As it had to on the white legs disappearing into the green

Water, and the expensive delicate ship that must have seen

Something amazing, a boy falling out of the sky,

Had somewhere to get to and sailed calmly on.

In this poem, Auden intends to emphasize the suffering and the tragedy of man in different aspects of life which has no any sort of impact on the rest of the world. In the first stanza he points to the fact that mundane activities go on while humans are suffering and feeling pain. Life daily routine never stops for a while so as to show any sign of sympathy or kindness towards humans. With regard to this issue, Auden says that the dogs go on with their doggy life and the horse scratches its innocent on a tree; indicating that everything continues as usual. So, no reaction is taken in order to offer any help for those who needs it or try to rescue those who are in great danger.

In the second stanza, Auden depicts another scene after he visited a museum in Brussels. There he was captivated by a masterpiece called 'Fall of Icarus '; painted by Breughel, an artist. In this scene the painter portrays the falling of Icarus from the sky into the sea. According to mythology, Icaus and his father were imprisoned by King Minos, later Icarus decided to escape from the prison by flying to the sky with fabricated wings made of feathers and fixed with wax.. Icarus ignored his father's warnings and flew high until he got close to the sun. As a result, the wax melted and Icarus, immediately, fell from the sky into the sea. Eliot states that no effort was exerted so as to rescue the boy who fell into the sea. He depicts the indifference of those who saw the miserable accident saying that the farmers who were working on their plantation heard the great splash, but they went on their usual work paying no attention to what they observed. Not only the farmers, but also the crew of the ship saw that disastrous scene and they didn't take any positive decision towards the matter. In fact, it is known that a crew of ship is aware of rescuing people from being drowned because they have the devices that enable them to do that such as life jackets. However, they didn't show any response or sense of humanity towards the disaster. Their only response to see the white legs of the boy disappearing into the water; was to describe the catastrophe as something amaze. Later, the ship sailed calmly away doing its daily routine which indicates that humans life doesn't matter.

\section{Findings}

This study was carried out in order to highlight the suffering of humans, as a universal phenomenon, and the indifference of others towards this suffering. By seeking to achieve the aims assigned for this study, the occurrence and the frequency of the words and phrases expressing and indicating the suffering of humans and the indifference of others towards them were calculated. Table 1 and table 2, in the section of discussion, showed that both poems, 'Morning at the Window' and 'Musee des Beaux Arts', highlight the suffering of humans and the disregard of others towards it.The findings displayed that the poems, investigated in this study, shed light on human suffering. They also displayed that humans are incurious and unenthusiastic to man serious problems and disasters. They show an insensitive and cruel disregard for others.

\section{Conclusion}

Poetry has the ability to reflect the reality of man's life by depicting all its aspects. Therefore, through poems humans feelings and passions can be awakened. Based on this fact, it is observed that the two poems investigated in this study have been used as a platform from which the poets launch a direct attack at humans allover the world. Throughout the history of humanity, the world has witnessed various great disasters such as wars, floods, starvations and pandemics. Although the two poems were written many years ago criticizing human beings passive roles towards the serious problems and agony of man, they still do the same task. For instance, corona virus pandemic can be taken as a prominent example of humans calamity towards the suffering of other people. This calamity can be observed in the negativity of different nations and communities in terms of helping poor counties and societies. There are many millions of people dying everywhere who need various kinds of aid such as respirators and medicines. In addition to, many people are not adhere to the precautionary measures such as wearing masks, sanitizing and leaving safe distances. Consequently, corona virus cases increase in great number and may result in death cases. Besides, the economic impact which has resulted in a great drop in the output of various companies and a lot of other economic institutions. Consequently, many people lost their jobs; therefore poverty is likely to increase among different communities. Thus, the indifference of humans towards disasters affect livelihoods in all its aspects. The poems also, draw attention to the fact that employees are exploited by the employers whatever they are; companies or individuals. As a result, employees are forced, in some cases, to work from the morning till midnight including weekends; and without little or no breaks. They may work under tension, 
stress and frustration, doing different tasks which are supposed not to be equal to the payment they receive. Poor employees are, sometimes prevented from their rights such as harassment, medical care and holidays.

Eventually, the investigated poems, in particular, and poetry, in general, function as a direct call addressing humans wherever they are in order to have a sense of empathy towards the poor, oppressed and persecuted. Furthermore, several crucial procedures should, highly, be conducted so as to keep human rights.

\section{Recommendation}

The researcher recommends that future studies and researches should be conducted on other forms of literary genres other than poetry. Besides, examining other social issues that can be of great importance to humanity, for literature is regarded as the mirror which reflects human life in all its aspects.

\section{About the Author}

Dr. Mohamed Jabraddar Mahil Abdallah is an assistant professor at Northern Border University, Faculty of Education and Arts. His research interests include linguistics and literature. He participated in some conferences and workshops. He published articles in linguistics and literature. ORCID:https://orcid.org/0000-0002-8622-4034

\section{References}

Abd Allah, M. J. (2021). The Value of Night in the English Poetry of the Romantic Period (1757-1822). International Journal of Applied Linguistics \& English Literature, 10(1).

A Shah, B. (2018) Why poetry is one of the most powerful forms of therapy. Retrieved from https://booktherapy

Handley, G. (2021). The Lessons of New World Poetry. Retrieved from https://humanities.byu.edu/the-lessons-ofnew-world-poetry

Matterson, S., \& Jones, D. (2000). Studying Poetry. London: Bloomsbury Academic.

Simecek, K., \& Rumbold, K. (2016). The Uses of Poetry. Changing English, 23(4), 309-313. https://doi.org/10.1080/1358684X.2016.1230300

Simpson, P. (2003). Language Through Literature. London: Taylor \& Francis. https://doi.org/10.4324/9780203137918

Stephen, M. (1984). An Introductory Guide to English Literature. Oxford UniversityPress: Oxford.

Wainwright, J. (2018). Poetry: The Basic. London \& New York: Rot=utledge.

Watson, J. R. (1992). English Poetry of the Romantic Period (1789-1830). AddisonWisely New York: Longman.

Zapruder, M. (2021, July 10). Understanding Poetry is More Straightforward than you think. The New York Times.

\section{Copyrights}

Copyright for this article is retained by the author(s), with first publication rights granted to the journal.

This is an open-access article distributed under the terms and conditions of the Creative Commons Attribution license (http://creativecommons.org/licenses/by/4.0/). 